\title{
PERFORMANCE OF NEW Hevea CLONES FROM IAC 400 SERIES
}

\author{
Paulo de Souza Gonçalvesi*; Marcelo de Almeida Silva²; Adriano Tosoni da Eira Aguiarr'; \\ Maria Alice Martins ${ }^{1}$; Erivaldo José Scaloppi Junior ${ }^{3}$; Lígia Regina Lima Gouvêa ${ }^{1}$ \\ ${ }_{2}^{1}$ Apta/IAC - Programa Seringueira, Av.Barão de Itapura, 1481, C.P. 28 - 13020-902 - Campinas, SP - Brasil. \\ ${ }^{2}$ Apta/DDD - Pólo Regional Centro Oeste, C.P. 66 - 17201-970 - Jaú, SP-Brasil. \\ ${ }^{3}$ Apta/DDD - Pólo Regional Noroeste Paulista, C.P. 61 - 1550-970 - Votuporanga, SP - Brasil. \\ *Corresponding author <paulog@iac.sp.gov.br >
}

\begin{abstract}
The Hevea breeding program of Instituto Agronômico de Campinas (IAC) has completed clonal evaluation on the following series: IAC 100, IAC 200 and IAC 300 . The performance of 22 clones of Hevea brasiliensis (Willd. ex Adr. de Juss.) Muell.-Arg., evolved at IAC, over a period of eleven years was evaluated in the Western Central part of the São Paulo State, Brazil. Among these 22 new clones, six were intraspecific hybrid clones (IAC 400, IAC 404, IAC 405, IAC 406, IAC 410, IAC 412) and the remaining are primary those resulted from selected ortets within half-sib progenies. An old popular clone RRIM 600, of Malaysian origin, was used as the control. The trial was laid out in a randomized block design with three replications. Yield performance over a period of four years, mean girth at the $11^{\text {th }}$ year, girth increment before tapping and on tapping, thermal property of natural rubber produced, bark thickness, number of latex vessel rows in seven year virgin bark, percentage incidence of tapping panel dryness, wind damage and diseases like leaf and panel anthracnose have been observed. Sixty one percent of the clones were superior in relation to the control for yield. The clone IAC 400 recorded the highest yield $\left(97.40 \mathrm{~g}^{\text {tree }} \mathrm{tap}^{-1}\right)$ over four years of tapping, followed by IAC 411 (78.87 tree $^{-1} \operatorname{tap}^{-1}$ ), whereas the control clone RRIM 600 recorded $50.86 \mathrm{~g} \mathrm{tree}^{-1} \operatorname{tap}^{-1}$. All selected clones were vigorous in growth. Girth increment of these clones was average to above average. Except for IAC 423, other clones had thick virgin bark at opening ranging from $4.84 \mathrm{~mm}$ for IAC 401 to $6.38 \mathrm{~mm}$ for IAC 416. The natural rubbers from IAC clones have shown good thermal stability up to $300^{\circ} \mathrm{C}$ and no differences in the thermal behavior among rubber from clones of the IAC series and the clone RRIM 600 were found in inert atmosphere.
\end{abstract}

Key words: Hevea brasiliensis, yield, vigour, brown bast, bark thickness

\section{PERFOMANCE DE NOVOS CLONES DE Hevea DA SÉRIE IAC 400}

RESUMO: O programa de melhoramento de Hevea do Instituto Agronômico de Campinas (IAC) completou a avaliação dos clones da série IAC 100, IAC 200 e IAC 300. O desempenho médio em torno de 22 clones de [Hevea brasiliensis (Willd. ex Adr. de Juss.) Muell.-Arg.], desenvolvidos pelo IAC, por um período de 11 anos foi avaliado na região Centro Oeste do estado de São Paulo. Dentre os 22 novos clones, seis são resultantes de hibridação intraespecífica (IAC 400, IAC 404, IAC 405, IAC 406, IAC 410, IAC 412) e o restante, clones primários resultantes de ortetes selecionados dentro de progênies de meios irmãos. O clone RRIM 600, de origem Malaia, foi usado como testemunha. O experimento foi conduzido sob delineamento de blocos ao acaso com três repetições. Desempenho da produção sob o período de quatro anos, média do perímetro do caule no décimo primeiro ano, incremento médio anual do perímetro antes e durante a sangria, espessura de casca, número de anéis de vasos laticíferos no sétimo ano de casca virgem, análise por termogravimetria da borracha produzida, percentagem de incidência de seca do painel de sangria, danos causados pelo vento e doenças como antracnose do painel e das folhas foram observados. A maioria dos clones foi superior em produção em relação ao clone RRIM 600. O clone IAC 400 registrou a mais alta produção $\left(97,40 \mathrm{~g}^{\text {rrvore }}{ }^{-1}\right.$ sangria $\left.^{-1}\right)$ em quatro anos de sangria o qual foi seguido pelo IAC $411\left(78,87 \mathrm{~g}\right.$ árvore $^{-1}$ sangria $\left.^{-1}\right)$ visto que o clone testemunha registrou 50,36 $\mathrm{g}_{\text {árvore }}{ }^{-1}$ sangria $^{-1}$. Todos os clones selecionados tiveram crescimento vigoroso. Incrementos do perímetro do caule estiveram acima da média. Exceto o IAC 423, outros clones apresentaram espessura de casca virgem na abertura do painel (mm) variando de $4.84 \mathrm{~mm}$ (IAC 401) a $6.38 \mathrm{~mm}$ (IAC 416). As borrachas estudadas apresentaram boa estabilidade térmica até cerca de $300^{\circ} \mathrm{C}$ e não foram observadas diferenças no comportamento térmico entre as amostras dos clones da série IAC e as do clone RRIM 600.

Palavras-chave: Hevea brasiliensis, produção, vigor, secamento do painel, espessura de casca 


\section{INTRODUCTION}

The "Instituto Agronômico" (IAC) started in 1942 a breeding and selection program for Hevea brasiliensis (Willd. ex Adr. de Juss.) Muell.-Arg. clonal cultivars. Since then, the institute has tested about 366 clones in small-scale clone trials and 43 clones in largescale clone trials (Gonçalves, 2002). In addition, IAC has also carried out tests on clones produced by other research organizations within and outside the country. IAC has now completed the clonal evaluation of the following series, IAC 100, IAC 200 and IAC 300 (first selection). Currently, field tests on the new, IAC 400 series clones are being carried out.

For Hevea, selective hybridization between superior clones as well as ortet selection (plus tree selection) followed by vegetative multiplication and evaluation, could produce many promising clones. Improved clones evolved by adopting these two techniques are used as planting materials since 1958 in the São Paulo State (Cunha, 1963a; 1963b; 1966, Gonçalves et al., 1997; Gonçalves, 2002). The experimental evaluation of clones is very elaborate, involving three stages of which the small scale trial is the second stage.

Attempts were made to extend rubber cultivation to the non-traditional regions of Brazil in which near tropical climatic conditions prevail (Ortolani, et al., 1998). One such region identified is South Western Brazil $\left(19\right.$ to $\left.23^{\circ} \mathrm{S}\right)$ where the continental up land of the region is an escape area of South American Leaf Blight (SALB) (Camargo et al., 1967; Ortolani et al., 1983; Gasparotto \& Lima, 1991) and the daily and monthly high rainfall or continuous water excess are not related to high latex production. The crop yield models described for this continental plateau for soybeans (Camargo et al., 1986) and for oranges (Camargo et al., 1995) indicate surplus as penalization factor for development and production.

In the present study, the performance of twenty-two IAC 400 series clones along with RRIM 600 an old popular clone taken as control, is presented for the first time, in a small scale trial carried out over a period of 11 years.

\section{MATERIAL AND METHODS}

The experiment was carried out in Jaú, Western Central São Paulo State, Brazil (22 ${ }^{\circ} 17^{\prime}$ S; 48 $34^{\circ}$ 'W and $580 \mathrm{~m}$ elevation), mean annual rainfall $1,344 \mathrm{~mm}$, on a Kandiudox of good nutrient status and physical structure. This location represents the most important continental area of non traditional rubber production in Brazil.
Genetic materials used in the experiment were 22 Hevea genotypes (clones) evolved by IAC and one developed by the Rubber Research Institute of Malaysia (RRIM 600) taken as control. The clones were budded on established GT 1 clonal rootstocks in a nursery. One-and-a-half-year-old rootstock seedlings raised in nurseries were used to budgraft the clonal materials. The successful budgrafts were uprooted and planted in plastic bags. The experiment was planted in the field after the first flush of leaves.

The small scale trial consisted of a randomized complete block design with three replications, using ten trees per row, with $7.0 \mathrm{~m} \times 3.0 \mathrm{~m}$ spacing. Missing plants were replaced with spares during the first two years after planting to maintain plantation density, but were not scored. One row of the clone RRIM 600 , acquired from a commercial nursery, was planted around the plot. Annual fertilizations consisted of $400 \mathrm{~g}$ of 10-10-10 formula NPK per plant, according to Bataglia \& Gonçalves (2003).

The trees were opened for tapping at the seventh year. The followed tapping system was the half spiral four daily tapping system (seven tappings per month), 11 month per year. Important characters recorded were dry rubber yield tree ${ }^{-1}$ tap $^{-1}$ in grams over four years, girth of the trees eleven years after planting, girth increment before and on tapping, thickness as well as latex vessel rows of seven years virgin bark, per cent incidence of wind damage, tapping panel dryness and major diseases under normal prophylactic conditions for annual latex production.

Attempts were made to record four annual yields after panel opening. Yield recording was made by the cup coagulation method on two normal tapping days per month i.e., by coagulating the latex from individual trees accumulated in collecting cups by adding $2 \%$ acetic acid solution and stirring. The coagulated rubber was pressed into a cylinder, hand-dried for 30 days, and weighed for calculation of the dry rubber mass.

Girth of each tree was recorded once a year at a height of $120 \mathrm{~cm}$ above the bud union with a tailors' tape. The first measurement at 12 months consisted of diameters, since the plants were too small to measure girth. Plant diameter was measured $0.50 \mathrm{~cm}$ above ground level with a slide clipper. This measurement was converted to girth, assuming that the stem was cylindrical. Thickness of the bark was measured with a Scheliper's guage. To record the number of latex vessel rows, bark samples were sectioned in the radial plane, stained with Sudan III and the number of latex vessel rows was counted using a light microscope. The incidence of diseases was assessed by visual observation. Data on yield, yield depression, girth, 
bark thickness and latex vessel rows were statistically analyzed.

For the panel anthracnose evaluation caused by the Colletotrichum gloeosporioides (Penz.) Sacc., the system of severity degree was used to quantify the intensity of symptoms of the disease in the panels. The evaluation was made using a gradual grade scale varying from 1 to 5 (1. low; 2. below average; 3 average; 4. above average; 5 . high). Data were transformed in infection indexes according to Bajungu (1977).

Thermogravimetric analysis of the rubber from the clones IAC 400, 401, 402, 403, 404, and RRIM 600 was obtained in a TA instrument model Q500, in the temperature range of $25^{\circ} \mathrm{C}$ to $800^{\circ} \mathrm{C}$, at a heating rate of 10 degree/min, in a nitrogen atmosphere.

All statistical analyses were performed using the Genes computer program, windows version, 2001 (Cruz, 2001).

\section{RESULTS AND DISCUSSION}

The annual combined analyses for variance for rubber yield and annual girth increment showed genetic variation among clones and years. This difference indicates good perspectives for the selection of clones. The experimental coefficients of variation were higher for girth increment. The low coefficient of variation for rubber yield suggests the need of a greater accuracy in the field. The year effect yielded significant values for both characters. The effect of the clones $\times$ year interaction was also significant showing that these characters were affected by the variation between years.

\section{Yield}

Two methods of comparing yield for all the clones were used (Table 1). Each method has its particular value. First, the mean yield per tree per tapping allows a comparison of the yield potential of the trees and does not take into consideration differences in the numbers of trees in relation to tapping. The mean yield is calculated from the yields of all recorded trees in tapping during the year. Second, the actual yields per hectare per year give a comparison in which a clone with high yield per tree, but with a low number of trees under tapping, may appear to be of the same productive value as another clone with a low yield per tree but a higher number of trees under tapping. To assess the value of a clone both types of yield, records need to be examined together. However, in the early years of tapping the yield per tree is a better indication of the yield potential than is the yield per hectare because of the wide differences in tappability or tappable stand per hectare among clones at opening (Tan, 1987).
Mean yield for the first four years, annual mean, percentage control and relative rank are given in Table 1. The yield potential of these clones over first three years has already been reported by Gonçalves (2006). Yield figures for the first year period indicated that $70 \%$ of the clones were numerically superior to the control and that IAC 400 had the highest yield of $69.89 \mathrm{~g} \mathrm{tree}^{-1} \operatorname{tap}^{-1}$. The next highest in yield were IAC 406 and IAC 405 with $56.65 \mathrm{~g}$ and $56.13 \mathrm{~g}$, respectively. The control clone RRIM 600 yielded on average $32.03 \mathrm{~g}$. During the period of second, third and fourth years of tapping, clones IAC 405 and IAC 406 yielded $70.00 \mathrm{~g}, 75.48 \mathrm{~g}, 77.35 \mathrm{~g}, 68.30 \mathrm{~g}, 75.73 \mathrm{~g}$, and $88.13 \mathrm{~g}$ of dry rubber per tree tapping, respectively. The control clone RRIM 600 yielded on average $54.54 \mathrm{~g}, 52.07 \mathrm{~g}$, and $64.78 \mathrm{~g}$, respectively.

The mean yield over four years of exploitation had shown differences in rubber yield. Clones IAC 400 and IAC 411, over four years of exploitation, out yielded all other clones recording $97.40 \mathrm{~g}$ and 78.87 $\mathrm{g}$, which means $192 \%$ and $155 \%$ superior to the clone control, respectively. The yield of the control clone RRIM 600 was only 50.86 g. Fourteen clones were superior to the control in this aspect. Gonçalves (2006) also reported that IAC 406, IAC 405, IAC 410, IAC 412 and IAC 413 were the top yielders over the period of three years. Analysis of winter yield depression has indicated that most of the clones are superior to the control regarding summer yield. IAC 400 had remarkable months $(8.30 \%)$.

\section{Secondary characters}

Girth at $7^{\text {th }}$ and $10^{\text {th }}$ year, mean girth increment before and on tapping, and mean bark thickness, number of latex vessel rows of seven years virgin bark tappability were separately ranked within the selected clones (Table 2).

\section{Vigour}

The high yielding clone IAC 413 recorded the highest girth $(62.33 \mathrm{~cm})$ at the $10^{\text {th }}$ year, while the control clone, RRIM 600 , presented only $52.14 \mathrm{~cm}$. The lowest girth was noticed in another high yielding clone, IAC $420(47.43 \mathrm{~cm})$. This is in agreement with the statement that high yield needs not necessarily to be associated with high girth increment (Gonçalves et al., 2006). The percentage of tappable trees varied between $29 \%$ (IAC 411) to $82 \%$ (IAC 423), at opening. As mentioned earlier, the trials were opened for tapping at different ages varying from five and a half to seven years. Clones are also not uniformly present in the trial. Therefore, it is necessary to standardize the age in the trial, in order to make a fair comparison of the girths between the clones. Mean girths at the first three years 


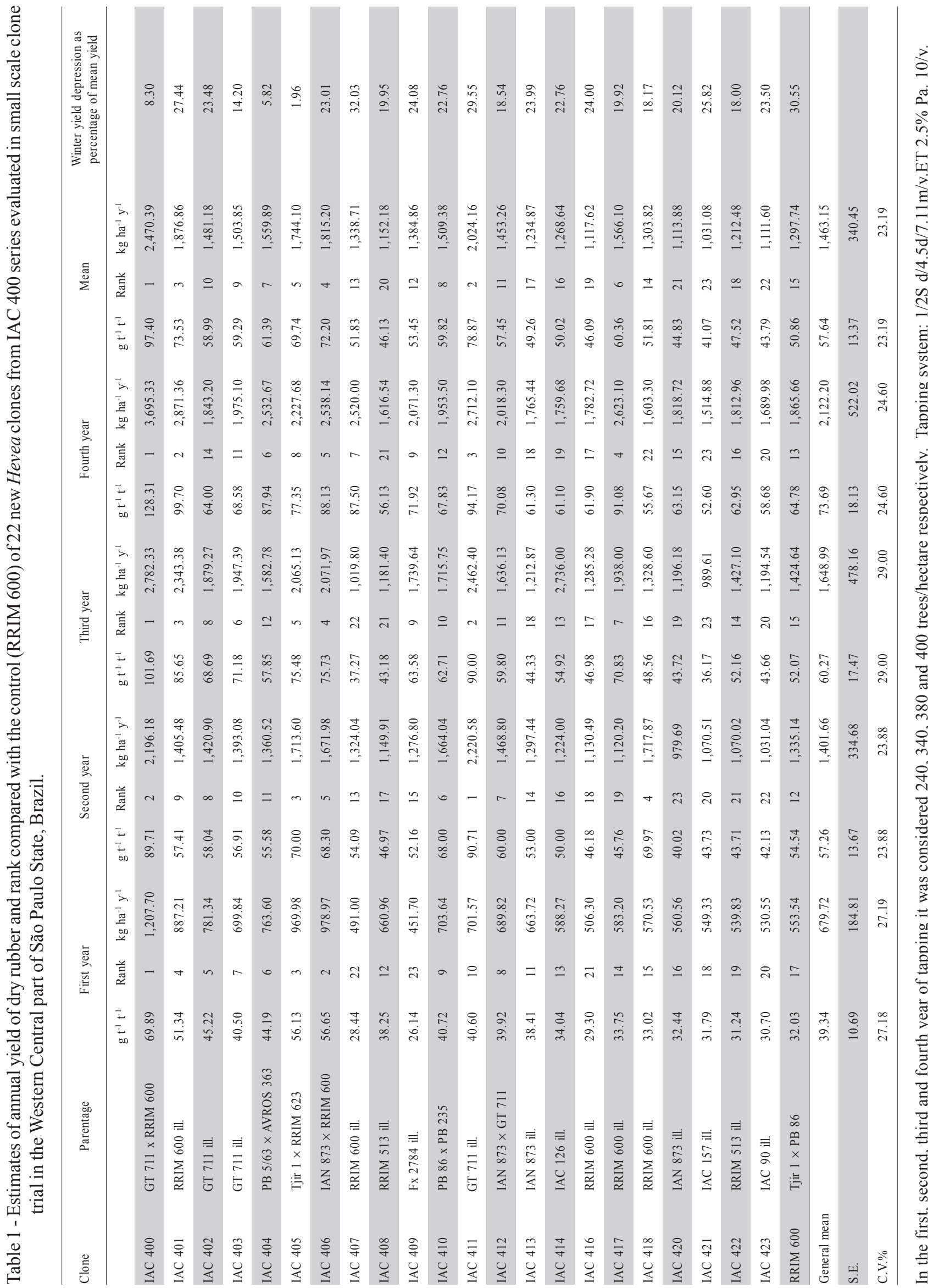




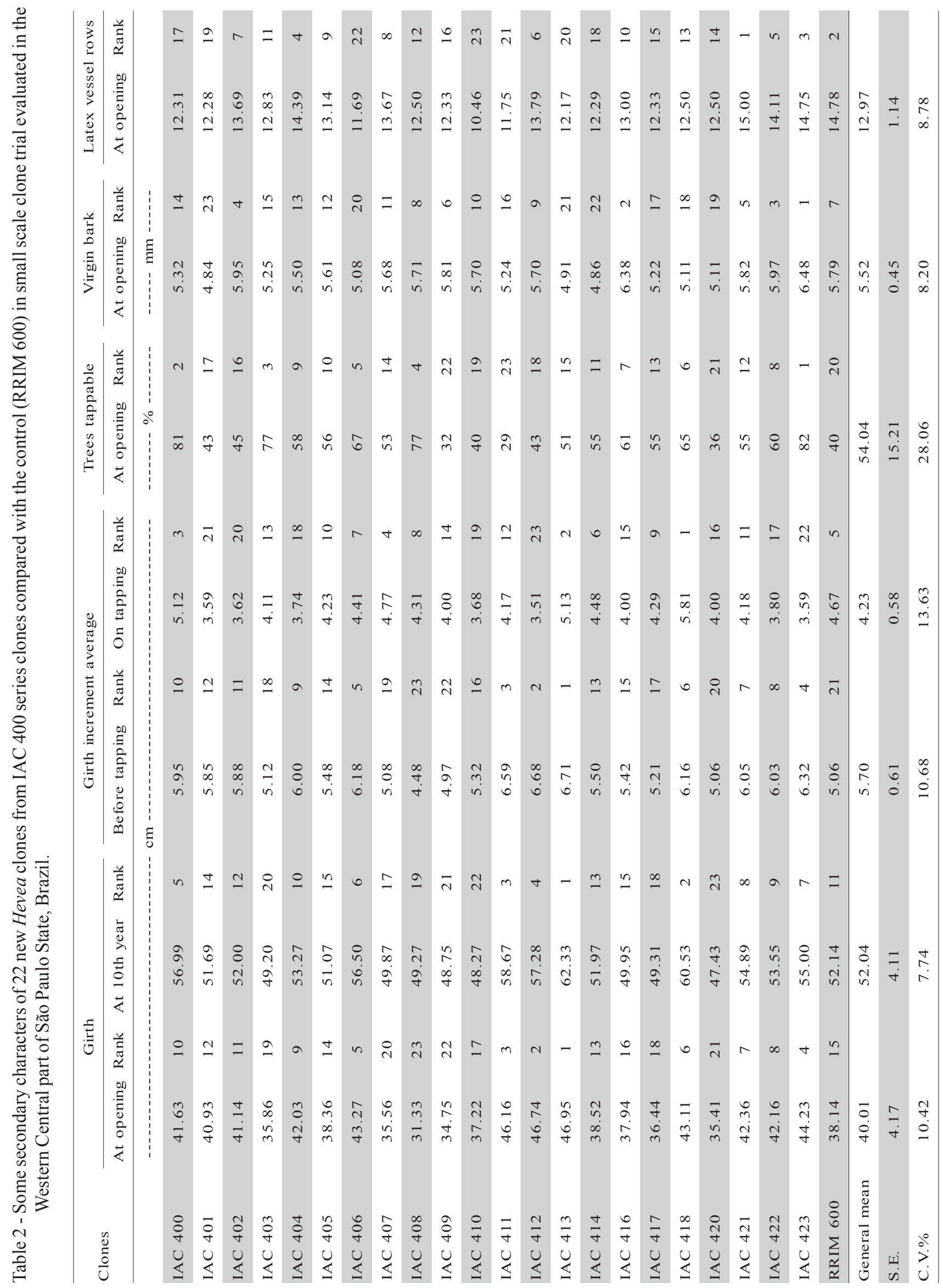


have been found to be highly correlated with mean girths at opening (Sultam, 1973). Hence, the former is used in preference for the assessment of the clones.

\section{Girth increment}

Mean girth increment per year before tapping ranged from a minimum of $4.48 \mathrm{~cm}$ (IAC 408) to a maximum of $6.71 \mathrm{~cm}$ (IAC 413). Gonçalves (2006) reported the highest girth at opening for IAC 413 . The control clone RRIM 600 recorded mean girth increment of $5.06 \mathrm{~cm}$ before tapping. The rate of girth increment during the tapping period, over three years also varied among the clones. The clones IAC 418 and IAC 413 showed the highest girth increment of 5.81 $\mathrm{cm}$ and $5.13 \mathrm{~cm}$ per year, respectively, followed by IAC $400(5.12 \mathrm{~cm})$, IAC $407(4.77 \mathrm{~cm})$ and IAC 414 $(4.48 \mathrm{~cm})$, which were found to be very poor in this regard when compared to other clones. Girthing rate on tapping is important when considering future yield and wind damage (Tan, 1987). In addition, good girthing in tapping according to Tan (1987) sustains yield and a reduce wind damage losses through trunk snap.

\section{Bark thickness}

In the case of bark thickness of seven-year virgin bark, all the clones were also found to be similar to the control. IAC $423(6.48 \mathrm{~mm})$ recorded the highest bark thickness while IAC $401(4.84 \mathrm{~mm})$ recorded the lowest. Tan (1987) reports that thick bark is very important because it minimizes wounding incidence, which is known to affect yield productivity on later panels.

\section{Number of latex vessels rings}

At opening, in relation to virgin bark, only IAC 421 clone was superior to the control and was found ranging from 10.46 (IAC 410) to 15.00 (IAC 421). In the control, the number was 14.78 rings. The number of vessel rings according to Henon \& Nicolas (1989) appeared to be the best parameter, among others, that influence the latex production. Its correlation with yield established by means of the Morris-Mann test for early tapping of seedlings is very good $(\mathrm{r}=0.64)$. Tixier (1953) examined the same relation in ten six-year-old clones and obtained a correlation coefficient $r$ of 0.75 . However, observation of AVROS 226, a low-yielding clone with many latex vessel rings, led him to take into account other criteria, such as girth and bark thickness, in the evaluation of rubber yield.

\section{Wind damage}

Only trees lost through trunk snap, uprooting and those that were stumped above $2 \mathrm{~m}$ were considered as losses due to wind damage. The incidence of wind damage occurring in different forms of trunk snap, branch snap and uprooting, up to the $10^{\text {th }}$ year of growth, was recorded and is given in Table 3. All the clones were affected by wind and the incidence varied from $1.03 \%$ (IAC 400) to $10.15 \%$ (IAC 416). The control clone RRIM 600 recorded $3.20 \%$ wind damage. Tolerance to wind minimizes losses ensuring a good tapping stand throughout the economic life of the crop that may be associated with branching habit, three height, long latex flow or low plugging index, leading to an adverse partition and hence an imbalance between crown and trunk components (Tan, 1987).

\section{Dry trees}

Only genuine cases of dry trees have been considered; trees that became dry as consequence of wind damage have been excluded. Dry tree incidences were also recorded (Table 3) over one-and-a-half years of tapping. As mentioned earlier, all trial trees were uniformly tapped on $S / 2 d / 4$. However, clonal susceptibility to dryness can be better assessed only after several years of tapping, (Sultan, 1973). Incidence of tapping panel dryness was noticed in almost all the clones. IAC 407 was the most susceptible clone, which recorded $3.67 \%$ incidence of dryness, followed by IAC 403 (3.65\%) and IAC 405 (3.52\%).

\section{Disease susceptibility}

All clones were found to be more or less susceptible to Anthracnose leaf and panel disease caused by Colletrichum gloeosporioides (Panz.) Sacc. within which six viz. IAC 402, IAC 403, IAC 404, IAC 405, IAC 406 and IAC 420, showed comparatively low incidence under normal prophylactic conditions (Table 3). Other clones were severely affected by this malady. Anthracnose panel disease also affected all clones with intensity varying from high to low. Based on the present study, four clones viz. IAC 406, IAC 410, IAC 412 and IAC 413 were found to be superior with respect to the Antracnose panel disease. According to Gonçalves et al. (1999) only recently, Anthracnose panel disease incidence was detected in tapping panels of the clone RRIM 600 by Silveira et al. (1992), on which where genetic studies were initiated. This disease has since assumed epidemic proportions in many rubber plantations in the São Paulo State (Trindade \& Furtado, 1997).

\section{Thermal properties}

Typical curves TG/DTG obtained for raw rubber from the IAC series 400 clones in inert atmosphere (Figures 1 and 2) show that the TG curve has only one large plateau and the DTG curve has one degradation peak, indicating that thermal degradation of raw natural rubber of the IAC clones is a one-stage reaction. The temperature of the maximum mass loss rate 
Table 3 - Percentages of wind damage, tapping panel dryness and incidence of anthracnose leaf and panel disease in 22 new clones from IAC 400 series in small scale trial evaluation in the Western Central part of São Paulo State.

\begin{tabular}{|c|c|c|c|c|}
\hline \multirow{2}{*}{ Clones } & \multirow{2}{*}{ Wind damage } & \multirow{2}{*}{ Tapping panel dryness } & \multicolumn{2}{|c|}{ Anthracnose disease incidence } \\
\hline & & & Leaf & Panel \\
\hline & (n-1 & - & & \\
\hline IAC 400 & 1.03 & 2.82 & Below average & Below average \\
\hline IAC 401 & 4.22 & 3.48 & Below average & Above average \\
\hline IAC 402 & 3.44 & 1.29 & Low & Above average \\
\hline IAC 403 & 6.20 & 3.65 & Low & Above average \\
\hline IAC 404 & 3.31 & 3.43 & Low & Above average \\
\hline IAC 405 & 2.10 & 3.52 & Low & Below average \\
\hline IAC 406 & 2.10 & 2.66 & Low & Low \\
\hline IAC 407 & 5.93 & 3.67 & High & Above average \\
\hline IAC 408 & 4.67 & 2.54 & High & Above average \\
\hline IAC 409 & 9.32 & 2.57 & Average & Average \\
\hline IAC 410 & 2.28 & 2.38 & Below average & Low \\
\hline IAC 411 & 4.61 & 0.81 & Average & Average \\
\hline IAC 412 & 1.22 & 1.61 & Average & Low \\
\hline IAC 413 & 2.18 & 2.83 & Average & Low \\
\hline IAC 414 & 3.12 & 1.61 & Below average & Below average \\
\hline IAC 416 & 10.15 & 2.81 & Above average & Above average \\
\hline IAC 417 & 5.14 & 2.38 & Above average & Above average \\
\hline IAC 418 & 4.70 & 2.54 & Below average & Average \\
\hline IAC 420 & 3.10 & 0.00 & Low & Average \\
\hline IAC 421 & 9.83 & 2.57 & High & Average \\
\hline IAC 422 & 5.61 & 1.29 & Below average & Average \\
\hline IAC 423 & 4.81 & 2.80 & Below average & Average \\
\hline RRIM 600 & 3.20 & 3.11 & Average & Average \\
\hline
\end{tabular}

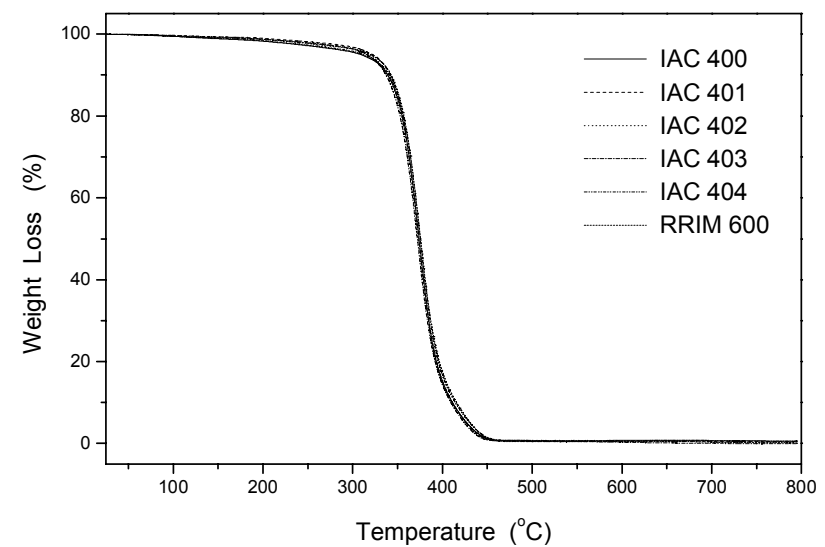

Figure 1 - TG curves of the IAC 400 series, and RRIM 600 clones in inert atmosphere. $10^{\circ} \mathrm{C} / \mathrm{min}$.

or the peak temperature of the DTG curve is around $375^{\circ} \mathrm{C}$, and at $800^{\circ} \mathrm{C}$ the content of residues was insignificant for all clones. This lower content of residues indicates that few impurities have been added during the extraction process of the latex in the planta-

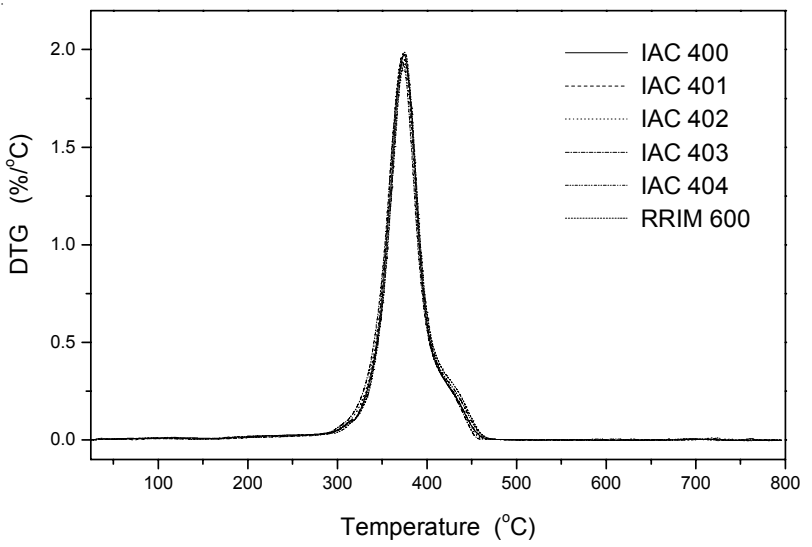

Figure 2 - DTG curves of the IAC 400 series, and RRIM 600 clones in inert atmosphere. $10^{\circ} \mathrm{C} / \mathrm{min}$.

tion. A small shoulder can be observed at approximately $430^{\circ} \mathrm{C}$ attributed to the slow decomposition of the most entanglement or crosslinked chains (Rippel, 2005). The temperature at which $50 \%$ decomposition occurs is generally considered as an index of thermal 
stability (Menon et al., 1996), and our results have shown that this temperature for the rubber from IAC clones is about $375^{\circ} \mathrm{C}$ indicating good thermal stability. TG and DTG curves of all clones have shown similar behavior, suggesting that the thermal decomposition mechanism is the same.

\section{ACKNOWLEDGMENTS}

To Paulo Boller Gallo for helpful comments and to Miss Graziela dos Santos Lima for the organization of this manuscript. To FAPESP, CNPq, and Secretaria de Agricultura e Abastecimento do Estado de São Paulo (SAA) for financial support.

\section{REFERENCES}

BATAGLIA, O.C.; GONÇALVES, P. de S. Tecnologia da adubação da seringueira. Informativo Apabor, v.9, p.3-4, 2003.

BAJUNGU, H.E. Avaliação de perdas de colheitas causadas pelos patógenos. Piracicaba: ESALQ, 1977. 37p.

CAMARGO, A.P.; CARDOSO, R.M.G.; SCHMIDIT, N.C. Comportamento do mal-das-folhas da seringueira nas condições climáticas do planalto paulista. Bragantia, v.26, p.1-8, 1967.

CAMARGO, M.B.P.; BRUNINI, O.; MIRANDA, M.A.C. Modelo agrometeorológico para estimativa de produtividade para a cultura da soja no Estado de São Paulo. Bragantia, v.45, p.279-292, 1986.

CAMARGO, M.B.P.; PEDRO JR., M.J.; ORTOLANI, A.A.; ROSA, S.M. Desenvolvimento e teste de modelo agrometeorológico de estimativa da produtividade de laranjais. In: CONGRESSO BRASILEIRO DE AGROMETEREOLOGIA, 9., Campina Grande, 1995. Anais. Campina Grande: Sociedade Brasileira de Agrometeorologia, 1995. p.412-414.

CUNHA, J.F. A cultura experimental da seringueira no município de Caraguatatuba. Bragantia, v.22, p.27-28, 1963 a.

CUNHA, J.F. A cultura experimental da seringueira na fazenda Unidos do Sul em Juquiá. Bragantia, v.22, p.651-656, 1963b.

CUNHA, J.F. A seringueira no Vale do Paraíba. Bragantia, v.25, p.129-144, 1966.

CRUZ, C.D. Programa Genes: aplicativo computacional em genética e estatística. Viçosa: Editora UFV, 2001. 648p.

GASPAROTTO, L.; LIMA, M.I.P.M. Research on South American leaf blight (Microcyclus ulei) of rubber in Brazil. Indian Journal of Natural Rubber Research, v.4, p.83-90, 1991.

GONÇALVES, P. de S. Uma história de sucesso: a seringueira no Estado de São Paulo. O Agronômico, v.54, n.1, 2002.

GONÇALVES, P. de S. Melhoramento genético da seringueira (Hevea spp.) para o Estado de São Paulo. Relatório técnico final - Projeto Temático. Campinas: Fapesp, 2006. 219p. (Processo nº 96/01268-0).

GONÇALVES, P. de S.; MARTINS, A.L.M.; ORTOLANI, A.A.; CARDOSO, M. Melhoramento genético da seringueira uma revisão. Campinas: Instituto Agronômico, 1997, 55p. (Documento, 54).
GONÇALVES, P. de S.; FURTADO, E.L.; BATAGLIA, O.C.; ORTOLANI, A.A.; MAY, A.; BELETTI, G.O. Genetics anthracnose panel canker disease resistance and its relationship with yield and growth characters in half-sib progenies of rubber tree (Hevea brasiliensis). Genetic and Molecular Biology, v.22, p.583-589, 1999.

GONÇALVES, P. de S.; SILVA, M. de A.; GOUVÊA, L.R.L.; SCALOPPI, JR., E. Genetic variability for girth growth and rubber yield characters in Hevea brasiliensis. Scientia Agricola, v.62, p.246-254, 2006.

HENON J.M.; NICOLAS, D. Relation between anatomical organization of the latex yield: search for early selection criteria In: AUZAC, J.; JACOB, J.L.; CRESTIN, H. (Ed.). Physiology of rubber tree latex. Boca Raton: CRC Press, 1989. p.31-50.

MENON, A.R.R.; PILLAI, C.K.S.; NANDO, G.B. Thermal degradation characteristics of natural rubber vulcanizates modified with phosphorylated cashew nut shell liquid, Polymer Degradation and Stability, v.52, p.265-271, 1996.

ORTOLANI, A.A.; PEDRO JR., M.J.; ALFONSI, R.R.; CAMARGO, M.B.P.; BRUNINI, O. Aptidão agroclimática para regionalização da heveicultura no Brasil. In: SEMINÁRIO NACIONAL PARA RECOMENDAÇÃO DE CLONES DE SERINGUEIRA, 1., Brasília, 1983. Anais. Brasília: EMBRAPA/SUDHEVEA, 1983. p. 19-28.

ORTOLANI, A.A.; SENTELHAS, P.C.; CAMARGO, M.B.P.; PEZZOPANE, J.E.M.; GONÇALVES, P. de S. Agrometeorologial model for seasonal rubber tree yield. Indian Journal of Natural Rubber Research, v.11, p.8-14, 1998.

RIPPEL, M.M. Caracterização microestrutural de filmes e partículas de látex de borracha natural. Campinas: Unicamp, 2005. 319p. (Doctoral Thesis).

SILVEIRA, A.P.da; FURTADO, E.L.; LOPES, M.E.B.M. Antracnose: nova doença do painel de sangria de seringueira. Summa Phytopathologica, v.18, p.195-200, 1992.

SULTAN, M.O. Assessment of some new clones for the future. In: RRIM PLANTERS CONFERENCE, Kuala Lumpur, Malaysia, 1973. Proceedings. Kuala Lumpur: Rubber Research Institute of Malaysia, 1973. p.281-299.

TAN, H. Strategies in rubber tree breeding. In: ABBOTT, A.J.; ATKIN, R.K. (Ed.). Improving vegetatively propagated crops. London: Academic Press, 1987. p.27-62.

TRINDADE, D.R.; FURTADO, E.L. Doenças da seringueira [Hevea brasiliensis (Willd. ex. Adr. de Juss) Muell.-ARg.]. In: KIMATI, H., AMORIM, L., BERGAMIM FILHO, A., CAMARGO, L.E.A. \& REZENDE, J.A.M. (Ed.). Manual de fitopatologia; doenças de plantas. 3.ed. São Paulo: Agronômica Ceres, 1997. p.628641 .

TIXIER, P. (1953) Examen anatomique des écorces d'Hevea. Paris: Institut de Recherches sur le Caoutchouc en Indochine, 1953. 112p. (Annual Report).

Received June 28, 2006

Accepted March 23, 2007 